\author{
Joanna Ptak \\ Piotr Serafin
}

\title{
Osiedla grodzone i ocena ich zamknięcia w krakowskiej dzielnicy Podgórze
}

\section{Streszczenie}

Coraz liczniej powstające osiedla grodzone, często autonomiczne i niespójne z otoczeniem, są oceniane negatywnie i przyczyniają się do fragmentaryzacji przestrzeni. Celem artykułu jest określenie przyczyn oraz skutków powstawania osiedli grodzonych w polskich miastach, określenie stopnia zamknięcia osiedli i ocena ich postrzegania w otoczeniu. Za obszar badawczy wybrano krakowską dzielnicę Podgórze, w której przedmiotowe zjawisko występuje z dużym nasileniem. Przeprowadzone badania potwierdzają wskazywane w literaturze oceny takich jednostek i prowadzą do konkluzji, że opisywane zjawisko należy postrzegać negatywnie, a w zakresie oceny stopnia zamknięcia osiedli niewłaściwe jest rozpatrywanie wszystkich jednostek grodzonych w ten sam sposób, ponieważ stopień ich zamknięcia jest różny. Ma to bezpośredni wpływ na postrzeganie tych osiedli i może przekładać się na relacje międzyludzkie zachodzące na ich obszarze oraz w najbliższym otoczeniu.

Słowa kluczowe: osiedla grodzone, gettoizacja, dzielnica Podgórze, Kraków, miasta. Klasyfikacja JEL: R11.

Joanna Ptak, e-mail: joaptak@gmail.com

Piotr Serafin, Uniwersytet Ekonomiczny w Krakowie, Wydział Gospodarki i Administracji Publicznej, Kateda Gospodarki Regionalnej, ul. Rakowicka 27, 31-510 Kraków, e-mail: serafinp@uek.krakow.pl 


\section{Wprowadzenie}

Osiedla grodzone to współcześnie jedno z najbardziej pożądanych miejsc do życia w miastach i na obszarach podmiejskich. Są one ciekawą formą przestrzeni wydzielonej, dostępnej tylko dla osób uprawnionych i na zasadach zarządzającego przestrzenią. Większość nowych inwestycji jest budowana i reklamowana pod hasłami bezpiecznych i prestiżowych. Sprawia to, że wiele osób inwestujących w nieruchomości mieszkaniowe jest zainteresowanych kupnem mieszkania w osiedlach grodzonych, kupujący dążą do tego, aby zamieszkać pod tzw. dobrym adresem. Zamykanie osiedli niesie jednak wiele negatywnych skutków społecznych i przestrzennych. Zjawisko to jest widoczne w wielu miejscach na świecie, przy czym w Polsce jego skala jest niepokojąca.

Celem opracowania jest wskazanie rzeczywistych przyczyn oraz skutków powstawania osiedli grodzonych w polskich miastach, określenie stopnia zamknięcia osiedli i ocena ich postrzegania w otoczeniu. Za obszar badawczy wybrano krakowską dzielnicę Podgórze, w której zjawisko to występuje z dużym nasileniem.

Realizacja celu zakładała przegląd literatury z zakresu gettoizacji przestrzeni miejskich, zestawienie wyników badań opinii eksperckich dotyczących przyczyn i skutków powstawania osiedli zamkniętych, wyrażonych przez praktyków w zakresie urbanistyki, rozwoju miast, planowania przestrzennego, socjologii miast i dziedzin pokrewnych oraz ocenę zamknięcia osiedli dokonaną na podstawie percepcji elementów infrastruktury wykorzystywanych do fizycznego oraz mentalnego ograniczenia dostępu do nich. W podsumowaniu przybliżono koncepcję secure by design jako alternatywę dla powszechnie stosowanego grodzenia osiedli.

\section{Osiedla grodzone i ich typy jako przejaw dobrowolnej gettoizacji}

Przestrzeń miejska jest strukturalizowana i zorganizowana nieprzypadkowo, a jej główną cechą jest zachodzenie interakcji społecznych o różnych funkcjach, powstających na skutek społecznego wytwarzania przestrzeni, czyli jako efekt działań ludzi w społecznie i historycznie ukształtowanych strukturach. A. Karwińska podmioty wytwarzające przestrzeń społeczną definiuje jako „działające jednostki, ukształtowane przez proces socjalizacji i wychowania, pełniące rozmaite funkcje i zajmujące określone miejsce w hierarchiach społecznych" [Karwińska 2008, s. 21-22]. Uważa ponadto, że aktorami wytwarzającymi przestrzeń społeczną są zarówno pojedyncze jednostki, jak i grupy jednostek. 
Proces gettoizacji i powstawanie gett jest skutkiem zachowań ludzkich w postaci segregacji społecznej. Segregacja ta jest powodowana chęcią ludzi do zachowania wyznawanych przez siebie norm kulturowych i społecznych, wartości i stylu życia [Węcławowicz 2007, s. 116] oraz dążeniem do oddzielania się od grup ludzi innych, tzn. posiadających odmienne zasady i normy społeczne, wyznających inne religie bądź pochodzących z innych kręgów kulturowych. Zjawisko segregacji najczęściej jest kojarzone z mniejszościami religijnymi, rasowymi bądź etnicznymi i często skutkuje wykluczeniem społecznym (social exclusion). Przeciwieństwem segregacji oraz wykluczenia jest asymilacja, czyli zmniejszanie różnic kulturowych między grupami społecznymi [Węcławowicz 2007, s. 116]. Asymilacja to „stapianie się” kultur, mieszanie i współegzystowanie ludzi z różnych kręgów kulturowych. Brak asymilacji oraz segregacja przestrzenna skutkują dyskryminacją społeczną. Jedną z metod takiej dyskryminacji jest strategia blokowania - są to działania mieszkańców mające na celu zniechęcenie nowo przybyłych do zamieszkania na danym terenie [Węcławowicz 2007, s. 16]. Polegają one na okazywaniu wrogości i niechęci, odmowie wynajmu czy sprzedaży mieszkań. Do segregacji przestrzennej przyczyniają się również ceny nieruchomości. W mieszkaniach tańszych będą mieszkać ludzie ubożsi, a w miejscach droższych, bardziej luksusowych i lepiej wyposażonych - ludzie bogatsi.

Pojęcie gettoizacji może być interpretowane na różne sposoby. W niektórych definicjach będzie ograniczone do izolacji przymusowej, a w innych będzie dotyczyło również dobrowolnego oddzielania się. Niezależnie jednak od sposobu definiowania gettoizacji należy podkreślić, że zawsze dotyczy ona podziałów międzyludzkich i zawsze zachodzi na dwóch płaszczyznach: społecznej i przestrzennej. Ten rodzaj segregacji przestrzenno-społecznej jest zjawiskiem, które pojawiło się na szeroką skalę w latach 80. XX w. w Stanach Zjednoczonych, a obecnie jest również powszechnym zjawiskiem w miastach europejskich. Gettoizacja w Europie nie przyjmuje pierwotnego wymiaru, dąży się bowiem do asymilacji mniejszości narodowych i integracji społeczeństw, ale przyjmuje drugi wymiar, tzn. ludzie dobrowolnie tworzą getta, zwane przez G. Węcławowicza enklawami.

Fizycznym skutkiem i zarazem metodą gettoizacji jest powstawanie osiedli grodzonych, tzw. gated communities [Węcławowicz 2007, s. 124]. Zjawisko to zostało zapoczątkowane w Stanach Zjednoczonych wraz z budową osiedli dla osób starszych i szybko rozpowszechniło się na wszystkie grupy społeczne. Wiąże się z potrzebą izolacji, ale jest także sposobem na obronę własnego systemu wartości, ochronę rodziny i poszukiwanie idealnej, homogenicznej wspólnoty. Gated communities najczęściej definiowane są jako wyodrębniona przestrzeń na skutek specjalnie zaprojektowanych fasad i form budynków oraz układu wszystkich wydzielonych elementów, m.in. pasów zieleni, ogrodzeń i bram, które stanowią barierę o charakterze fizycznym, uniemożliwiającą swobodne wejście 
na teren osiedla osobom z zewnątrz. Dodatkowe zabezpieczenie zapewniają firmy ochroniarskie oraz systemy monitoringu. Ograniczenie dostępu nie dotyczy tylko budynków czy posesji, ale także ulic, chodników oraz całej infrastruktury technicznej i społecznej znajdującej się wewnątrz takiego osiedla [Tobiasz-Lis 2011, s. 99-114]. E. Blakely i M. Snyder definiują je jako osiedla „których mury i płoty wykluczają publiczny dostęp do ulic, chodników, parków, plaż, rzek i placów zabaw (...) wszystkich zasobów, które bez tych bram i murów byłyby otwarte i używane przez wszystkich obywateli" [Gądecki 2007, s. 28]. E. McKenzie osiedla grodzone definiuje jako inwestycje wspólnych zainteresowań (common interest housing development), co jest próbą szerokiego określenia tego zjawiska [Tobiasz-Lis 2011, s. 99-114]. Na potrzeby artykułu zakłada się, że osiedla grodzone to obszary różniące się od otoczenia intensywnością i rodzajem zabudowy oraz fizycznym wyodrębnieniem z przestrzeni poprzez ograniczony dostęp.

Gated communities często tworzą prywatne kluby (club economy), przeznaczone dla ludzi bogatych lub posiadających pewne charakterystyczne, pożądane cechy (np. wiek, status społeczny, rasa) [Le Goix i Webster 2006, s. 41-62]. $\mathrm{Z}$ punktu widzenia finansowego, politycznego, gospodarczego czy ekologicznego są niezależne i mogą, poprzez dobre zarządzanie, być jednostkami bardziej ekologicznymi bądź lepiej prosperującymi od tych współpracujących z sektorem publicznym np. w zakresie gospodarki odpadami lub dbania o przestrzeń publiczną. Koszt społeczny takiej izolacji może być jednak znacznie wyższy od korzyści finansowych. Jednym z wielu skutków gettoizacji jest brak wymiany kulturowej, poczucie obcości i wrogości [Jałowiecki 2010, s. 301].

Zamknięte, odizolowane jednostki mieszkaniowe zazwyczaj są zorganizowane tak, aby były niezależne od otoczenia. Posiadają wysoki standard, różnią się rodzajem zabudowy i estetyką. Ma to ogromny wpływ na postrzeganie tych miejsc jako „swego rodzaju wysp” niepasujących do otoczenia. Ich granice zazwyczaj podkreślają różnice wewnątrz i na zewnątrz osiedla [Dymnicka 2007, s. 53]. Zaburza to krajobraz oraz sprawia, że jest niespójny i chaotyczny, a tym samym przyczynia się do zaburzenia ładu przestrzennego.

Ciekawą pracą dotyczącą gettoizacji dobrowolnej w ramach osiedli zamkniętych jest praca autorstwa E. Blakelya i M. Snydera [Grant i Mittelsteadt 2004, s. 913-930], w której na podstawie przeanalizowanych amerykańskich przykładów zaprezentowano najczęściej występujące typy osiedli, zidentyfikowane na podstawie przyczyn ich powstawania. Są nimi osiedla wspólnego stylu życia (lifestyle communities), osiedla prestiżu (prestige communities) i strefy bezpieczeństwa (security zones).

Lifestyle communities koncentrują ludzi wokół aktywnego spędzania wolnego czasu, obiektów sportowych lub rekreacyjnych, wspólnego dobra, współdzielonych usług [Grant i Mittelsteadt 2004, s. 913-930]. Oznacza to, że mieszkańcy takich 
osiedli mają podobne zainteresowania, potrzeby lub pragnienia. Atutem tego typu miejsc ma być możliwość utożsamienia się ze społecznością, bezpieczeństwo i identyczny styl życia wszystkich sąsiadów (np. osiedla dla emerytów). Społeczność w tym wypadku jest tworzona jako skutek wspólnej korzyści i wspólnych zainteresowań. Prestige communities są ekskluzywnymi osiedlami symbolizującymi bogactwo i status [Grant i Mittelsteadt 2004, s. 913-930]. M.G. Snyder i E.J. Blakely rozróżniają trzy podtypy wyróżnione na podstawie poziomu zamożności mieszkańców. Są nimi enclaves of rich and famous, top-fifth development i executive middle class. Pierwsze $\mathrm{z}$ nich to enklawy osób sławnych i najbogatszych, chronione, z ograniczonym dostępem, zawsze usytuowane w atrakcyjnej lokalizacji. Drugie, topowe inwestycje mieszkaniowe, są również chronione, co gwarantuje ograniczony dostęp dla osób z zewnątrz. Trzecia grupa osiedli jest zamieszkiwana przez bogatszą klasę średnią, która dąży do podniesienia swojego prestiżu. Według powyższej klasyfikacji osiedla dla klasy średniej są zazwyczaj grodzone (gated), ale nie chronione (guarded) i są najniżej usytuowane w hierarchii osiedli pod względem prestiżu. Security zone communities, czyli strefy bezpieczeństwa, powstają w wyniku potrzeby izolowania się [Grant i Mittelsteadt 2004, s. 913-930]. Skutkiem ich powstania jest zamykanie dróg publicznych dla osób niemieszkających na danym terenie oraz budowanie murów i ogrodzeń. Są one utożsamiane $\mathrm{z}$ ochroną przed przestępczością, ze zmniejszeniem ruchu i dbałością o własność prywatną. Motywem ich tworzenia jest poczucie strachu.

Podział zaproponowany przez amerykańskich naukowców może stanowić podstawę do określenia przyczyn występowania takiego zjawiska w Polsce. Należy jednak uwzględnić uwarunkowania historyczne, kulturowe, społeczne czy polityczne, które różnią się w Polsce od tych występujących w Stanach Zjednoczonych. Można założyć, że mimo odmiennych przyczyn izolowania się, skutki takiego działania mogą być podobne.

\section{Zjawisko grodzenia osiedli w Polsce po okresie przemian społeczno-ustrojowych XX wieku i jego przyczyny}

Po II wojnie światowej wraz z intensywną industrializacją kraju i rozwojem przemysłu wydobywczego i przetwórczego w krajobrazie miast pojawiły się robotnicze osiedla mieszkaniowe, w których mieszkali pracujący w przemyśle wraz z rodzinami. Mieszkańcami nowych industrialnych dzielnic byli migranci ze wsi, którzy wraz z podjęciem pracy w przemyśle osiągali awans społeczny. Przyrost ludności napływającej z obszarów wiejskich i szybko realizowane inwestycje mieszkaniowe z wielkiej płyty przyczyniły się do powstania chaosu przestrzennego. Tworzone były duże dzielnice nieposiadające centrum, placów, wartości 
kulturowej w postaci zabytków. Były to sztuczne twory, budowane na potrzeby istniejącej sytuacji. To nowe otoczenie, socrealistyczne i dalekie naturze, nazywane jest Indunature [Szczepański i Ślęzak-Tazbir 2007, s. 36-43]. Przykładem takich osiedli były inwestycje Huty Katowice, której pracownicy otrzymali mieszkania w Dąbrowie Górniczej, czy Huty im. Lenina, na której potrzeby powstała robotnicza Nowa Huta, będąca początkowo odrębnym miastem, a od $1951 \mathrm{r}$. przyłączona do Krakowa jako jego dzielnica. Wraz z reformą ustrojową w Polsce klasa robotnicza straciła swój uprzywilejowany status. Wiele zakładów zaczęto zamykać, co skutkowało wzrastającym bezrobociem i obniżeniem standardów życia. Osiedla zamieszkiwane przez byłych pracowników zakładów stawały się gettami biedy [Szczepański i Ślęzak-Tazbir 2007, s. 36-43]. Ludność zamieszkująca tam zaczęła ubożeć i borykać się z odseparowaniem od społeczeństwa. Problemy, których doświadczała, były m.in. skutkiem długotrwałego bezrobocia, popadaniem w nałogi i konfliktami z prawem.

Na skutek transformacji ustrojowo-gospodarczej klasa średnia zaczęła stanowić coraz ważniejszą grupę w społeczeństwie polskim. Znaczenie zyskiwał kapitał oparty na wiedzy, wykształceniu i kwalifikacjach zawodowych. Nowe społeczeństwo cechowała efektywność, tempo, osiągnięcia, postęp. Ludzie posiadający te cechy - zaliczani do klasy średniej - są obecnie najczęściej mieszkańcami gett dobrobytu, czyli nowoczesnych osiedli, otoczonych murem lub z wyraźnie wyodrębnioną przestrzenią [Szczepański i Ślęzak-Tazbir 2007, s. 43-47]. Obszary te często zachowują tradycyjny układ, posiadają ulice, place i tereny zielone. Zazwyczaj są one ładne, zadbane i dobrze zaprojektowane. Dodatkowo można zauważyć, że nazwy tych osiedli, a także wewnętrznych ulic przynoszą pozytywne skojarzenia, często sugerują prestiż i dobrobyt lub bajkowość i magiczność miejsca. Niestety zazwyczaj nie wpisują się w krajobraz, tworzą obszary wydzielone do tego stopnia, że można je nazwać miastem w mieście [Szczepański i Ślęzak-Tazbir 2007, s. 43]. Społeczne skutki takiego sąsiedztwa mogą być negatywne. Dzielenie fizyczne oraz mentalne ludności sąsiadującej ze sobą powoduje niechęć, zazdrość czy wrogość. Pojawia się rozróżnienie na gorszych i lepszych, biedniejszych i bogatszych. Uważa się, że ewentualne problemy na tym tle zależą od nastawienia społeczności i waloryzowania zamieszkiwanej przestrzeni. Istotna staje się tutaj świadomość pojawienia się różnych podziałów [Szczepańska 2012, s. 102-125]. Uznanie jakiegoś obszaru za gorszy prowadzi do marginalizacji jego mieszkańców. „Nierzadko dochodzi do eskalacji gniewu w dzielnicy biedy właśnie poprzez mechanizm etykietowania" [Szczepański i Ślęzak-Tazbir 2007, s. 49]. Dodatkowo, w społeczności, która wytwarza negatywne emocje i poczucie zagrożenia, pojedynczy człowiek dąży do odizolowania i alienacji.

W Polsce jedną z istotnych przyczyn powstawania osiedli za bramą stała się potrzeba poczucia bezpieczeństwa. B. Jałowiecki uważa, że ryzyko jest 
problemem współczesności. W dobie globalizacji poczucie zagrożenia jest stałe i skutkuje lękiem. W związku z tym powstają utopijne idee miast bezpiecznych i zamieszkiwanych tylko przez ,swoich”. Odpowiedzią na tę nierealną ideę mają być mniejsze jednostki, czyli bezpieczne, grodzone osiedla. Niestety trudno stwierdzić, czy zabezpieczenia oferowane mieszkańcom osiedli zamkniętych są skuteczne i rzeczywiście zapewniają bezpieczeństwo. Dają one natomiast poczucie „mentalne”, które przez B. Jałowieckiego zostało nazwane „obsesją bezpieczeństwa" [Jałowiecki 2007, s. 22]. Z. Bauman uważa, że taka zabudowa nie zmniejszy odczuwanego przez ludzi strachu, gdyż jest on spowodowany innymi czynnikami - niestabilnym rynkiem pracy, zmniejszającą się wartością nabywanych umiejętności i kompetencji, zanikającymi relacjami międzyludzkimi [Dymnicka 2007, s. 54]. Inną i częstą, lecz niechętnie wymienianą przez mieszkańców przyczyną wyboru tych osiedli jest prestiż takiego zamieszkania. W badaniach ankietowych respondenci nie przyznają się do chęci mieszkania w osiedlach prestiżowych, należy jednak uznać, że jest to istotna przyczyna wyboru tych osiedli.

\section{Analiza ocen eksperckich dotyczących przyczyn i skutków powstawania osiedli grodzonych oraz wpływu elementów infrastruktury na stopień zamknięcia osiedla*}

Badania zostały podzielone na dwie części - pierwsza część badań została oparta na wynikach wypełnianego przez ekspertów kwestionariusza, druga bazowała na szacowaniu stopnia zamknięcia osiedli na podstawie terenowej inwentaryzacji i zebranej dokumentacji fotograficznej. W grupie eksperckiej rangowane w kwestionariuszu opinie formułowało 23 teoretyków i praktyków, zajmujących się planowaniem przestrzennym, rozwojem miast, socjologią miast, architekturą i dziedzinami pokrewnymi ${ }^{1}$, którzy także proszeni byli o oszacowanie własnych kompetencji w zakresie ocenianych zagadnień. Przygotowany kwestionariusz pozwolił określić przyczyny rozwoju osiedli grodzonych oraz skutki społeczne i przestrzenne ich powstania, a także elementy infrastruktury, które warunkują zróżnicowany stopień zamknięcia osiedli. Uzyskane wyniki wykorzystano do

* Badania zostały przeprowadzone w ramach zajęć seminarium magisterskiego przez Joannę Ptak, pod kierunkiem Piotra Serafina.

${ }^{1}$ Byli to pracownicy Urzędu Miasta Krakowa (Biura Planowania Przestrzennego), pracownicy Instytutu Rozwoju Miast (Zespołu Planowania Przestrzennego i Komunikacji, Obserwatorium Polityki Miejskiej oraz Zakładu Przestrzennych i Społecznych Aspektów Mieszkalnictwa), pracownicy katedr: Gospodarki i Administracji Publicznej, Gospodarki Regionalnej, Katedry Socjologii Uniwersytetu Ekonomicznego w Krakowie oraz Katedry Socjologii Ogólnej i Antropologii Społecznej Akademii Górniczo-Hutniczej. 
oszacowania stopnia zamknięcia osiedli grodzonych w dzielnicy Podgórze w Krakowie. W niniejszej pracy nie przytoczono analiz statystycznych udzielanych odpowiedzi, a jedynie ich uogólnioną syntezę, warto jednak podkreślić, że przytoczone wnioski są efektem takich analiz, a uczestniczący w badaniach eksperci wysoko ocenili swoje kompetencje w zakresie tej problematyki.

Eksperci traktowali zjawisko gettoizacji szeroko, jako takie, które może mieć wymiar zarówno przymusowego, jak i dobrowolnego izolowania grup ludności, w różnych okolicznościach i z różnych powodów. Potwierdzili także, że osiedla zamknięte są przykładem gettoizacji. W grupie przyczyn wpływających na grodzenie osiedli najwyżej ocenianą przez respondentów była „chęć posiadania wyłącznego dostępu do infrastruktury i usług, np. miejsc parkingowych". W centrach miast, gdzie parkowanie samochodu w miejscach publicznych jest płatne, a liczba miejsc ograniczona, argument dotyczący potrzeby posiadania dostępu do miejsc parkingowych wydaje się racjonalny. Nie można jednak tego odnieść do parków, skwerów czy placów zabaw, gdzie dzieci nie mogą się wspólnie bawić, ponieważ mieszkają na różnych osiedlach. W wielu artykułach naukowych oraz prasowych rozpatruje się ten problem właśnie pod kątem najmłodszych użytkowników przestrzeni i ich reakcji na wzniesione ogrodzenia. Drugim w kolejności notowanym czynnikiem grodzenia osiedli jest „potrzeba zaznaczenia/oddzielenia swojej własności w przestrzeni”. „Potrzeba bezpieczeństwa oraz potrzeba prestiżu", które w literaturze są wskazywane jako jedne z najważniejszych przyczyn grodzenia osiedli, znalazły się na kolejnych, ale niżej punktowanych miejscach. Mniej istotnymi przyczynami w opinii respondentów są: „identyfikowanie się z tzw. klasą metropolitarną”, „,chęć tworzenia homogenicznej wspólnoty wewnątrz osiedla” oraz „uwarunkowania historyczne związane z okresem PRL-u (ukształtowanie nastawienia do dobra wspólnego, przestrzeni publicznych i prywatnych)". Ostatni z wymienionych czynników jest często podawany w literaturze jako czynnik mający istotny wpływ na relacje ludzie - przestrzeń. Ponadto ankietowani wskazali dwie dodatkowe przyczyny: „naśladowanie tendencji występujących w innych krajach” i „lepsza kontrola nad terenem - zabezpieczenia przed wandalizmem".

Pozytywne i negatywne konsekwencje tworzenia osiedli zamkniętych zostały ocenione w kategorii oddziaływań społecznych i przestrzennych, przy czym w ocenie dominowały te niekorzystne. Najbardziej niekorzystnym skutkiem według grupy eksperckiej jest „tworzenie społecznych podziałów ludzi”, kolejne to „zanik relacji sąsiedzkich i innych,, oraz „potęgowanie strachu, nieufności, poczucia zagrożenia”. Do skutków pozytywnych respondenci zaliczyli „realizowanie preferowanego stylu życia, zachowanie/kreowanie społecznej spójności w ramach tworzonej grupy” oraz ,podtrzymywanie tradycji i kultury”, są to jednak skutki o niewielkim znaczeniu. Zdecydowana większość wskazanych konse- 
kwencji przestrzennych została oceniona negatywnie. Jedyną zaletę grodzenia osiedli eksperci dostrzegli w „kondensowaniu wielu funkcji na małej przestrzeni”, zaś za najbardziej uciążliwe skutki uznali „tworzenie fizycznych barier” oraz „utrudnienia komunikacyjne dla pieszych”. Równie źle ocenianymi skutkami były: „ograniczanie przestrzeni dla ogółu”, „zmniejszanie ilości przestrzeni publicznych i utrudnienia komunikacyjne dla samochodów”, ,podział przestrzeni, tworzenie stref” oraz „wizualnych i widokowych barier".

Eksperci dokonali także oceny wpływu poszczególnych elementów infrastruktury na stopień zamknięcia osiedla. Wskazane w ocenie elementy zostały potraktowane jako mające istotne znaczenie w percepcji zamknięcia osiedli i zostały wykorzystane jako modelowe do oszacowania poziomu zamknięcia osiedli w krakowskim Podgórzu.

Ranga elementu (tabela 1) została ustalona jako uśredniona wartość iloczynów ocen wpływu danego elementu na zamknięcie osiedla w opinii ekspertów (ocenianego w skali 1-5) i ich samooceny w zakresie znajomości danego tematu (ocenianej w skali 1-5). Eksperci dokonywali samooceny, czyli oszacowania swoich kompetencji osobno w dwóch płaszczyznach: społecznego oraz przestrzennego aspektu gettoizacji. Podczas wyliczania rang dotyczących wpływu elementów infrastruktury na stopień zamknięcia brano pod uwagę samooceny odnoszące się do przestrzennego aspektu gettoizacji.

Według ekspertów największy wpływ na percepcję zamknięcia osiedla ma wysokie ogrodzenie (tabela 1). Jest to element w największym stopniu przyczyniający się do odczucia, że osiedle jest osiedlem zamkniętym. Wysoko rangowanym elementem jest również ogrodzenie nieprześwitujące. Połączenie tych dwóch elementów mocno wpływa na odbiór stopnia zamknięcia osiedla. Taki typ ogrodzenia stosowany jest jednak bardzo rzadko. Najlepiej ocenionym rodzajem ogrodzenia jest żywopłot. Ma on najmniejszy wpływ na odbiór zamknięcia osiedla. Siły odpowiedzi dotyczące wszystkich ocenianych elementów infrastruktury podano w tabeli 1.

Kolejnym wysoko rangowanym elementem jest furtka zamknięta (otwierana tylko po weryfikacji wchodzącego). Ciekawe, że według respondentów zamknięte wejście i wjazd wpływają podobnie silnie na odbiór stopnia zamknięcia osiedla, natomiast kiedy elementy te są otwarte, to odczuwalny stopień zamknięcia osiedla jest dużo mniejszy w przypadku, gdy otwarta jest brama wjazdowa, niż wówczas, gdy otwarta jest bramka wejściowa. Użycie szlabanu wjazdowego jest rozwiązaniem gorszym niż pozostawienie otwartej bramy, ale lepszym niż zamknięcie bramy. Wydaje się również lepszym rozwiązaniem dla pieszych niż zamontowanie bramki wejściowej, gdyż zgodnie z opinią ankietowanych ma mniejszy wpływ na odczuwalny stopień zamknięcia przestrzeni. W najmniejszym stopniu odczucie zamknięcia osiedla powodują: symboliczne zaznaczenie granicy, żywopłot oraz 
wjazd otwarty. Przez symboliczne zaznaczenie granicy rozumie się takie zabiegi projektowe, które sugerują występowanie granicy między dwoma obszarami, np. przez wykorzystanie elementów małej architektury, zieleni czy różnic terenu.

Tabela 1. Ocena wpływu poszczególnych elementów infrastruktury na stopień zamknięcia osiedla

\begin{tabular}{|l|c|}
\hline \multicolumn{1}{|c|}{ Oceniane elementy infrastruktury } & Ranga elementu ${ }^{\mathrm{a}}$ (0-25) \\
\hline Ogrodzenie wysokie & 18,91 \\
\hline Furtka zamknięta (otwierana tylko po weryfikacji wchodzącego) & 18,52 \\
\hline Ogrodzenie nietransparentne & 17,43 \\
\hline Wjazd zamknięty & 17,35 \\
\hline Obecność stróża & 13,57 \\
\hline Furtka otwarta (z możliwością zamknięcia) & 13,04 \\
\hline Ogrodzenie transparentne & 12,48 \\
\hline Znak informujący o zakazie wstępu/wjazdu & 12,00 \\
\hline Zewnętrzna firma ochroniarska & 12,00 \\
\hline Szlaban & 11,65 \\
\hline System monitoringu & 10,61 \\
\hline Ogrodzenie niskie & 10,57 \\
\hline Wjazd otwarty & 8,43 \\
\hline Żywopłot & 8,30 \\
\hline Symboliczne zaznaczenie granicy & 5,09 \\
\hline
\end{tabular}

a Ranga elementu była ustalana na podstawie uśrednionych wartości uzyskanych odpowiedzi, skorygowanych o samoocenę respondentów w zakresie ocenianego zagadnienia.

Źródło: badania własne.

Zaprezentowana synteza pierwszej części badań stała się źródłem wiedzy o postrzeganiu grodzonych osiedli jako swoistego negatywnego fenomenu, który nie powinien być rozwijany.

\section{Analiza i ocena stopnia zamknięcia osiedli grodzonych w dzielnicy Podgórze}

Drugim etapem prowadzonych badań było określenie stopnia zamknięcia wytypowanych osiedli grodzonych według stanu na wrzesień 2016 r., zlokalizowanych w krakowskiej dzielnicy Podgórze. Dzielnica ta została wybrana ze względu na największą liczbę nowych inwestycji mieszkaniowych w Krakowie w ostatnich dwóch latach. Dzięki inwentaryzacji, wizji lokalnej i zebraniu dokumentacji 
fotograficznej dotyczącej 28 osiedli $^{2}$ określono, w jakie elementy infrastruktury, wskazane i rangowane przez ekspertów pod kątem wpływu na izolację danej jednostki, jest wyposażone każde z nich. Ich występowanie było podstawą wyznaczenia skali izolacji i punktem wyjścia do obliczenia stopnia zamknięcia osiedla.

Stopień zamknięcia osiedla jest średnią arytmetyczną z rang poszczególnych elementów infrastruktury podanych w tabeli 1 i został wyliczony według wzoru:

$$
S_{z}=\frac{\sum_{i=1}^{m} s_{i}}{m}
$$

gdzie:

$S_{z}$ - stopień zamknięcia,

$s_{i}-$ wpływ elementów infrastruktury na stopień zamknięcia oszacowany $\mathrm{w}$ ankiecie,

$m$ - liczba ocenianych elementów infrastruktury $(m=15)$.

Wyznaczenie wzoru o powyższej formule miało na celu w możliwie łatwy sposób pozwolić na ocenę zamknięcia osiedli. Powstał on na podstawie ankiety, w której eksperci oceniali wpływ 15 elementów infrastruktury na stopień zamknięcia przestrzeni osiedla (w skali $0-25$ ). Stąd formuła wzoru stopnia zamknięcia uwzględnia elementy występujące na danym osiedlu pomnożone przez oszacowany stopień zamknięcia $\left(s_{i}\right)$, uśrednione poprzez podzielenie przez liczbę wszystkich branych pod uwagę wskaźników $(m=15)$.

Wszystkie wytypowane osiedla znajdują się w zachodniej części tej dzielnicy, gdyż umożliwia ona zabudowę mieszkaniową. Część wschodnia dzielnicy to w dużej mierze obszary niezagospodarowane bądź z zabudową mieszkaniową jednorodzinną lub niemieszkalną (często przemysłową). Wytypowane do badań osiedla często znajdują się w sąsiedztwie podobnych, zawyczaj minimum dwóch osiedli zamkniętych. Taką zależność zaobserwowano przy ul. Płaszowskiej, gdzie graniczą ze sobą cztery osiedla zamknięte. Podobne zagęszczenie osiedli zamkniętych można zaobserwować przy ul. Przewóz, gdzie w jej części zachod-

2 Analizowane osiedla mieszczą się pod wskazanymi adresami, jeśli istnieją, podano nazwy własne osiedli: I - ul. Szafrana 4, II - ul. Rydlówka 44, III - ul. Rydlówka 42, 42a, 42b, 42c, IV - Osiedle Fi, ul. Rzemieślnicza/Szafrana 5, 5a, 5b, 5c, 5d, V - Dom pod Słowikiem, ul. Krasickiego 30, VI - ul. Parkowa 16b, VII - ul. Parkowa 16, 16a, VIII - ul. Parkowa 18, IX - Pasaż Podgórski, ul. Romanowicza 5, X - ul. Przemysłowa 25, XI - ul. Przemysłowa 13, XII - Garden Residence, ul. Przemysłowa 4, XIII - ul. Wielicka 57, XIV - ul. Wielicka 42, 42a, 42b, 42c, XV - ul. Wielicka 44, XVI - osiedle Nad Stawem, ul. Krzywda 17a, 17g, 17h, XVII - ul. Strycharska 10, XVIII - ul. Sarmacka 10, 10a, 10b, 10c, XIX - ul. Płaszowska 51, 51a, 51b, 51c, 51d, 51e, XX ul. Płaszowska 57, 59, XXI - ul. Płaszowska 63, XXII - ul. Saska 5, 7, XXIII - Parkowa Siódemka, ul. Myśliwska 5, XXIV - ul. Ignacego Stoszki 9 i ul. Przewóz 9, XXV - ul. Przewóz 8, 10, 12, 14, XXVI - ul. Przewóz 13, XXVII - osiedle Nowy Przewóz, ul. Przewóz 32a, 32b, 38, 40, 40a, 40b, 40c, 40d, XXVIII - osiedle Mały Przewóz, ul. Przewóz 36, 36a, 36b. 
niej znajdują się trzy takie osiedla, a w części wschodniej dodatkowe dwa, przy czym jedno z nich jest największym osiedlem w Podgórzu. Inne miejsca o dużym skupisku osiedli zamkniętych to Zabłocie, gdzie znajdują się cztery takie osiedla, ul. Wielicka z trzema sąsiadującymi osiedlami, ul. Parkowa również z trzema sąsiadującymi osiedlami, a także rejon między ul. Rydlówka a ul. Rzemieślniczą, gdzie zlokalizowane są cztery osiedla zamknięte. Pojedyncze lokalizacje to osiedla przy ul. Krasickiego, Krzywda, Strycharskiej oraz Sarmackiej.

Większość, tj. 3/4 osiedli, posiada ogrodzenie. W każdym wypadku było to ogrodzenie transparentne wykonane z siatki ogrodzeniowej lub paneli ogrodzeniowych. W siedmiu przypadkach było to ogrodzenie niskie (do 1,5 m wysokości), a w czternastu wysokie (powyżej 1,5 m wysokości). W przypadku osiedli, gdzie nie było ogrodzeń od frontu budynku, znajdowały się szlabany wjazdowe ograniczające wjazd samochodów. Takie rozwiązanie występuje np. na osiedlach przy ul. Przemysłowej 13 i 25 oraz ul. Parkowej 16 i 16a. Najczęściej stosowanym zabezpieczeniem poza zamknięciem i ogrodzeniem jest system monitoringu posiada go 21 osiedli. Informację o ochronie przez zewnętrzną firmę ochroniarską zauważono na terenie ośmiu osiedli. Ochronę stróża odnotowano na terenie dwóch osiedli. Informacje o zakazie wstępu nieupoważnionym pojawiły się na sześciu osiedlach. W 22 przypadkach wjazd na teren osiedla nie jest możliwy, z czego w pięciu przypadkach uniemożliwiają go szlabany, a w 17 zamknięte bramy wjazdowe. Tylko na trzech osiedlach są otwarte bramy wjazdowe. Wejście do 3/4 osiedli prowadzi przez furtki wejściowe. Osiemnaście z nich było zamkniętych podczas inwentaryzacji terenowej, a tylko trzy otwarte, umożliwiające swobodne wejście na teren osiedla. Swobodne wejście było możliwe na teren co czwartego osiedla. Żadne z analizowanych osiedli nie posiada naturalnego żywopłotu jako granicy, ogrodzenia lub elementu zaznaczającego obszar osiedla.

Najtrudniejszym w ocenie elementem było symboliczne zaznaczenie granicy. Założono, że mogą to być elementy małej architektury stanowiące widoczne odróżnienie od otoczenia, a także zieleń różniąca się od otaczającej lub w sposób fizyczny oddzielająca teren osiedla od otoczenia. Takie zabiegi architektoniczne lub ogrodnicze zaobserwowano w dziewięciu przypadkach.

Jak wynika z tabeli 2, dwa na 28 osiedli posiada bardzo wysoki stopień zamknięcia (grupa I) - wartość wskaźnika 7,24. Są to osiedla, na których odnotowano najwięcej elementów infrastruktury wpływających na stopień zamknięcia. Pierwsze z nich, Dom pod Słowikiem zlokalizowany przy ul. Krasickiego, ma wysokie, transparentne ogrodzenie, elementy małej architektury stanowiące widoczną granicę osiedla oraz zamknięty dostęp na teren osiedla. Wejście lub wjazd jest możliwy po identyfikacji wchodzącego przez stróża. Osiedle jest dodatkowo zabezpieczane przez system monitoringu i zewnętrzną firmę ochroniarską. Drugim osiedlem o tak wysokim stopniu zamknięcia jest Garden Residence. 
Na osiedlu tym występują takie same elementy jak na osiedlu opisanym powyżej. Jest ono wyposażone w bramę i furtkę oraz oddzielny hall z recepcją i wejściem dla gości. Wstęp na teren osiedla jest możliwy po weryfikacji wchodzącego przez pracownika recepcji.

Osiedli, których stopień zamknięcia jest wysoki (wartość wskaźnika stopnia zamknięcia osiedla mieści się w przedziale 5-6,99) jest jedenaście (grupa II). Osiedla te posiadają zazwyczaj pięć, sześć, a w jednym przypadku siedem rozpatrywanych elementów infrastruktury. Osiedli o średnim stopniu zamknięcia (wartość wskaźnika w przedziale 3-4,99) jest siedem (grupa III). Są to osiedla posiadające cztery lub pięć elementów z piętnastu rozpatrywanych. Osiedli o niskim stopniu zamknięcia (wartość wskaźnika w przedziale 1-2,99) jest osiem (grupa IV). Posiadają one po dwa lub trzy, a w jednym przypadku cztery badane elementy infrastruktury.

Osiedlem o najniższym stopniu zamknięcia jest osiedle zlokalizowane przy ul. Rydlówka 44. Występują tu dwa elementy: symboliczne zaznaczenie granicy (użyto do tego barierek oraz stopni różnicujących wysokość terenu ulicy od osiedla) oraz system monitoringu. Drugim osiedlem o tej samej wartości stopnia zamknięcia 1,05 jest osiedle przy ul. Wielickiej 42, 42a, 42b, 42c. Posiada ono takie same dwa elementy, ale jest znacznie większe od poprzedniego. Na oba te osiedla można swobodnie wejść. Osiedla o niewiele wyższym wskaźniku $(1,82)$ to osiedla przy ul. Parkowej 16, 16a oraz ul. Przemysłowej 13 i 25. Występują tu trzy elementy: symboliczne zaznaczenie granicy, szlaban i system monitoringu. Są to elementy ograniczające poruszanie się samochodów, nie ograniczają jednak w żaden sposób ruchu pieszych, co sprawia, że odczuwalny stopień zamknięcia tego osiedla jest niski. Nieco wyższy stopień zamknięcia $(1,85)$ ma osiedle przy ul. Wielickiej 44. Na osiedle to nie jest ograniczony wjazd samochodów, gdyż na jego terenie nie ma szlabanu wjazdowego, ale zastępuje go informacja o ochronie przez zewnętrzną firmę ochroniarską. Zgodnie z opinią ekspertów informacja o takiej ochronie bardziej wpływa na odbiór wyższego stopnia zamknięcia niż szlaban wjazdowy.

Dwa pozostałe osiedla o niskim wskaźniku zamknięcia to Pasaż Podgórski przy ul. Romanowicza $5(1,92)$ oraz budynek przy ul. Strycharskiej $10(2,81)$. Pierwsze z wymienionych osiedli posiada trzy elementy: symboliczne zaznaczenie granicy, otwartą furtkę oraz system monitoringu. Osiedle to zaprojektowane jest tak, że przestrzeń z zewnętrznej części budynków jest dostępna dla ogółu. Na jego terenie znajduje się mała architektura oraz zieleń, a także usługi na parterze jednego z budynków. Przestrzeń ta zaprojektowana jest w sposób zachęcający przechodnia do skorzystania z niej. Przestrzeń od wewnętrznej części budynków jest przeznaczona dla mieszkańców. Furtka, umożliwiająca wejście na dziedziniec nie jest częścią ogrodzenia (osiedle to nie jest ogrodzone), lecz muru budynku. 


\begin{tabular}{|c|c|c|c|c|c|c|c|c|c|c|c|c|c|}
\hline 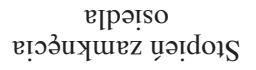 & $x$ & 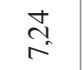 & 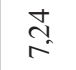 & लु. & $\begin{array}{l}n \\
n \\
n\end{array}$ & \begin{tabular}{l}
\multirow{2}{*}{} \\
$i$
\end{tabular} & $\underset{f}{J}$ & $\vec{r}$ & $\begin{array}{l}\infty \\
\text { ñ } \\
n\end{array}$ & $\stackrel{\infty}{i}$ & $\frac{\partial}{n}$ & $\frac{\partial}{n}$ & is \\
\hline 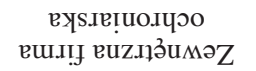 & $\stackrel{0}{\simeq}$ & + & + & + & + & & & & & + & & & + \\
\hline 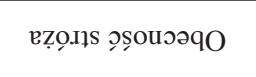 & $\begin{array}{l}n \\
n \\
n\end{array}$ & + & + & & & & & & & & & & \\
\hline 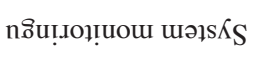 & $\stackrel{\overrightarrow{0}}{\circ}$ & + & + & & & + & + & + & & & + & + & + \\
\hline 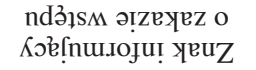 & $\stackrel{0}{\simeq}$ & & & + & + & + & + & + & + & & & & \\
\hline 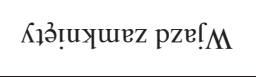 & $\stackrel{n}{n}$ & + & + & + & + & + & + & & + & + & + & + & + \\
\hline 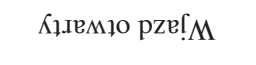 & $\underset{\infty}{\mathscr{q}}$ & & & & & & & + & & & & & \\
\hline 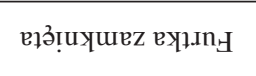 & $\begin{array}{l}\tilde{n} \\
\infty \\
\infty\end{array}$ & + & + & + & + & + & + & + & + & + & + & + & \\
\hline 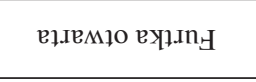 & 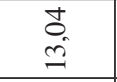 & & & & & & & & & & & & + \\
\hline urqe [zS & $\stackrel{n}{=}$ & & & + & & & & & & & & & \\
\hline 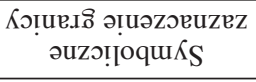 & $\begin{array}{l}\text { o } \\
\text { in }\end{array}$ & + & + & & & & & & & & & & \\
\hline џоłdoмK Z & $\infty$ & & & & & & & & & & & & \\
\hline 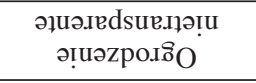 & $\stackrel{\mathscr{F}}{\stackrel{D}{\Xi}}$ & & & & & & & & & & & & \\
\hline 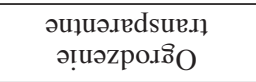 & $\stackrel{\infty}{\substack{c \\
c}}$ & + & + & + & + & + & + & + & + & + & + & + & + \\
\hline 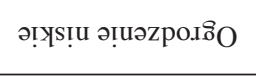 & $\stackrel{n}{n}$ & & & + & + & + & + & & & & & & + \\
\hline 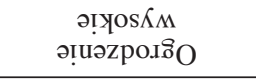 & ळ. & + & + & & & & & + & + & + & + & + & \\
\hline ednip & $x$ & - & $\neg$ & $=$ & $\exists$ & $\exists$ & ヨ & $\Xi$ & ヨ & ヨ & $\Xi$ & $\Xi$ & $\Xi$ \\
\hline 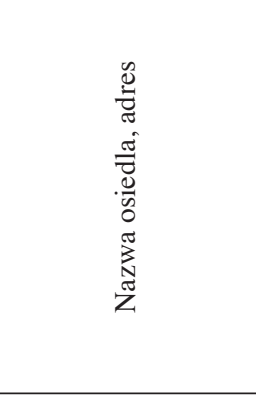 & 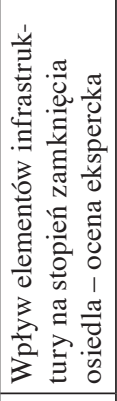 & 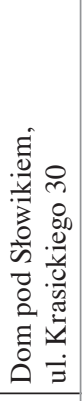 & 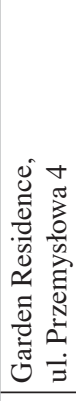 & 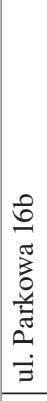 & 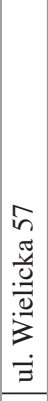 & 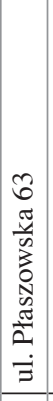 & 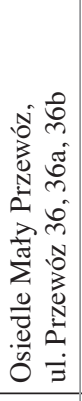 & 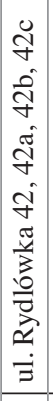 & 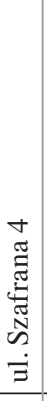 & 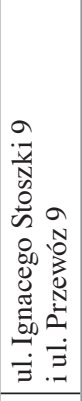 & 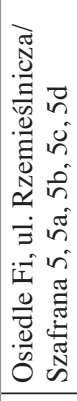 & 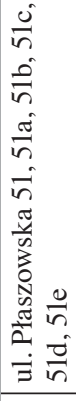 & 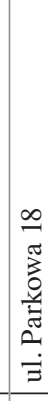 \\
\hline$\dot{1}$ & & - & N & $m$ & $\nabla$ & in & 0 & $r$ & $\infty$ & $a$ & & $=$ & $\simeq$ \\
\hline
\end{tabular}




\begin{tabular}{|c|c|c|c|c|c|c|c|c|c|c|c|c|c|c|c|c|}
\hline 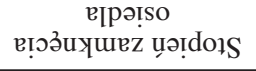 & $\begin{array}{l}8 \\
i \\
i\end{array}$ & 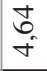 & $\begin{array}{l}\dot{t} \\
\stackrel{+}{+}\end{array}$ & $\begin{array}{l}\dot{t} \\
\stackrel{+}{*}\end{array}$ & $\begin{array}{l}\text { tu } \\
\dot{f}\end{array}$ & $\hat{m}$ & $\hat{m}$ & $\stackrel{\circ}{n}$ & $\stackrel{\infty}{i}$ & $\underline{-}$ & $\stackrel{n}{\infty}$ & $\underset{\leftarrow}{\infty}$ & $\begin{array}{l}1 \\
\infty \\
- \\
-\end{array}$ & $\begin{array}{c}1 \\
\infty \\
- \\
-\end{array}$ & $\stackrel{n}{0}$ & $\stackrel{n}{0}$ \\
\hline 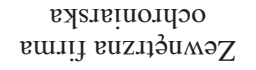 & + & & & & & & & & & & + & & & & & \\
\hline \multicolumn{17}{|l|}{ 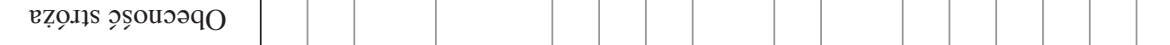 } \\
\hline 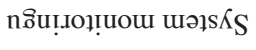 & + & + & + & + & + & & & & + & + & + & + & + & + & + & + \\
\hline \multicolumn{17}{|l|}{ 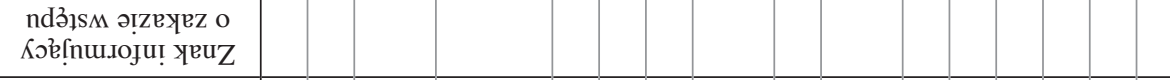 } \\
\hline 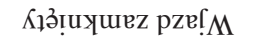 & & + & + & + & & + & + & + & & & & & & & & \\
\hline КұІЕМџо рzе!M & & & & & + & & & & + & & & & & & & \\
\hline 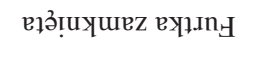 & + & + & + & + & + & + & + & & & & & & & & & \\
\hline 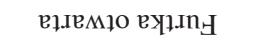 & & & & & & & & + & & + & & & & & & \\
\hline urqe[zS & + & & & & & & & & & & & + & + & + & & \\
\hline 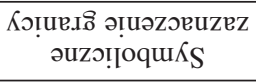 & & & & & & & & & & + & + & + & + & + & + & + \\
\hline \multicolumn{17}{|l|}{ юұdoмк Z } \\
\hline \multicolumn{17}{|l|}{ 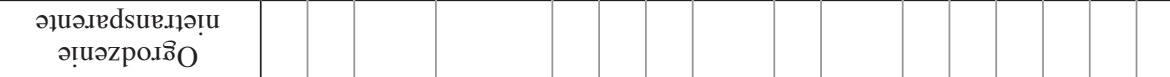 } \\
\hline 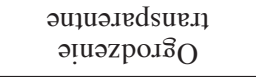 & + & + & + & + & + & + & + & + & + & & & & & & & \\
\hline 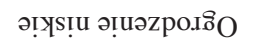 & + & + & + & + & + & + & + & + & + & & & & & & & \\
\hline \multicolumn{17}{|l|}{ 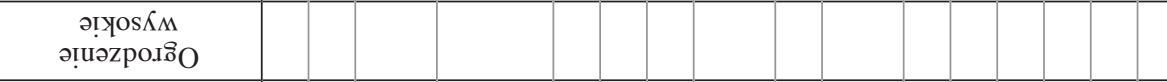 } \\
\hline edn.ID & $\exists$ & $\exists$ & $\Xi$ & $\Xi$ & $\Xi$ & $\Xi$ & $\Xi$ & $\Xi$ & $\geq$ & $\geq$ & $\geq$ & $\geq$ & $\geq$ & $\geq$ & $\geq$ & Z \\
\hline 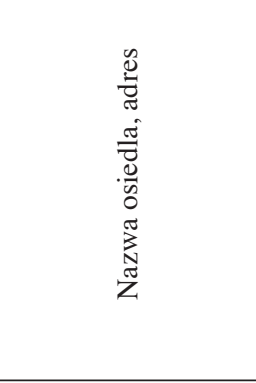 & 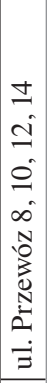 & 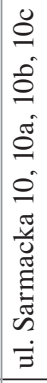 & 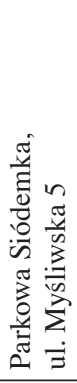 & 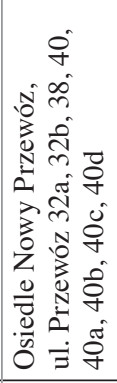 & 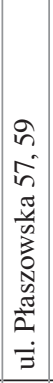 & 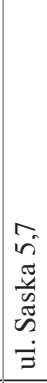 & $\begin{array}{l}0 \\
N \\
0 \\
D \\
0 \\
N \\
D \\
\\
\end{array}$ & 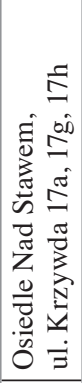 & 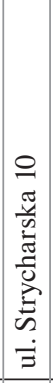 & 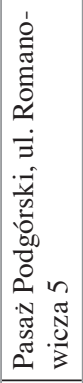 & 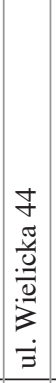 & 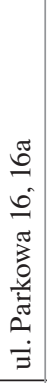 & 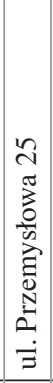 & 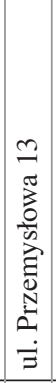 & 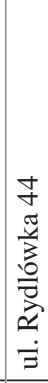 & 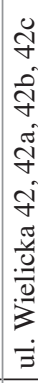 \\
\hline$\dot{1}$ & $\cong$ & \pm & 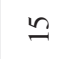 & 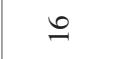 & 二 & $\infty$ & 9 & ฉิ & $\vec{\sim}$ & ป & $\ddot{\sim}$ & $\stackrel{\sim}{\sim}$ & $\ddot{\imath}$ & ¿ & ヘิ & $\stackrel{\infty}{\sim}$ \\
\hline
\end{tabular}


Inwestycja przy ul. Strycharskiej 10 to wielorodzinny budynek mieszkalny z usługami oraz przedszkolem na parterze. Wyposażony jest w niskie, transparentne ogrodzenie, lecz wjazd na jego teren jest otwarty, podobnie jak przejścia dla pieszych. Osiedle to posiada system monitoringu.

Na podstawie powyższych analiz można zaobserwować, że osiedle zamknięte to pojęcie używane do określania większości obecnie realizowanych inwestycji mieszkaniowych. Deweloperzy stosują różne formy zabezpieczeń i reklamują swoje osiedla jako bezpieczne i prestiżowe. Nazwy osiedli często mają wskazywać na luksus i renomę. Przeprowadzone analizy wykazały jednak, że nie wszystkie osiedla zamknięte należy rozpatrywać tak samo, ponieważ stopień ich zamknięcia jest różny. Zastosowanie szacowania stopnia zamknięcia dało możliwość oceny każdego z badanych osiedli, pozwoliło uwzględnić zastosowane elementy infrastruktury, które mają wpływ na izolację, oraz umożliwiło porównanie osiedli pod względem izolacji przestrzennej. Badane osiedla różnią się stopniem zamknięcia, co sprawia, że na niektóre z nich można wejść swobodnie, a do innych drzwi otwiera wyłącznie stróż. Jedne i drugie „odbierają” przestrzeń miastu, ale w różnym stopniu. Przeanalizowane przypadki wskazują, że istnieją rozwiązania mniej i bardziej inwazyjne, a odpowiedni dobór elementów infrastruktury sprawiłby, że mieszkańcy nie mieliby poczucia, że ich sąsiedzi się izolują. Percepcja zamknięcia byłaby dużo mniejsza, a to nie powodowałoby niechęci czy konfliktów na tej płaszczyźnie. Zastosowanie tylko niektórych elementów infrastruktury i w ograniczonym stopniu mogłoby wyeliminować pojawiające się problemy.

Istotny jest również sam odbiór przestrzeni. Eksperci zwracają uwagę, że ludzie zamieszkujący osiedla zamknięte często izolują się od otoczenia - nie zabiegają o relacje sąsiedzkie. Izolacja przestrzenna wpływa na izolację mentalną ludzi zamieszkujących takie osiedla. Przestrzeń kształtuje więzi, a jej depersonalizacja skutkuje depersonalizacją więzi.

Na koniec należy dodać, że zauważono również nieliczne zalety zamykania osiedli, na co wskazali eksperci: „Ludzie czują, że posiadają coś, co należy do nich, dbają o to miejsce, bo jest ich i oni z tego korzystają”, „Grodzenie osiedli ma pozytywny wpływ na ład przestrzenny - zabudowa często nie jest spisana/ wymalowana sprayami. (...) Ludzie często odczuwają satysfakcję z estetyki osiedli zamkniętych ze względu na czystość elewacji bloków”.

\section{Podsumowanie}

Trudno jednoznacznie określić, dlaczego osiedla zamknięte stały się tak popularne w przestrzeni polskich miast. W przeprowadzonych badaniach rozpatrywano różne aspekty tego zjawiska, nie dają one jednak jednoznacznej odpowiedzi na 
postawione pytania. Dla planistów, urbanistów, socjologów i innych osób zajmujących się tematyką miast oczywiste jest, że zjawisko to należy zaliczyć do negatywnych. Osiedla grodzone przyczyniają się do fragmentaryzacji przestrzeni [Jałowiecki 2010, s. 298-302]. Powstają liczne, często autonomiczne i niespójne z otoczeniem enklawy. Na skutek ich powstawania dochodzi do prywatyzacji przestrzeni, czyli zamykania dużych obszarów na użytek wyłącznie zamieszkiwanej przez nie społeczności. Ponadto przegradzane są ciągi komunikacyjne, zarówno piesze, jak i kołowe. Utrudnia to funkcjonowanie ludzi zamieszkujących obszary wokół takiego osiedla za bramą. „Zabieranie przestrzeni” miastu i jego mieszkańcom, a także tworzenie podziałów społecznych niewątpliwie ma złe skutki dla społeczeństwa. Dlatego też zjawisko gettoizacji jest traktowane jako jeden z głównych problemów polskich miast, tym bardziej że przybrało ono wyjątkowo dużą skalę.

Przeprowadzone badania wykazały, że niewłaściwe jest rozpatrywanie wszystkich osiedli grodzonych w ten sam sposób, ponieważ ich stopień zamknięcia jest różny. Ma to bezpośredni wpływ na postrzeganie tych osiedli, co może przekładać się na relacje międzyludzkie zachodzące na ich obszarze oraz w najbliższym otoczeniu. W wielu przypadkach osiedla te były całkowicie zamknięte, uniemożliwiając wejście na ich teren. Takie miejsca należy traktować jako całkowicie wyłączone z przestrzeni miasta. W niektórych przypadkach można było zaobserwować tylko częściową izolację, gdyż na terenie osiedli znajdowały się otwarte place zabaw bądź przedszkola pozwalające na poruszanie się $\mathrm{w}$ ich przestrzeni. Tak zaprojektowane osiedla umożliwiają szerszą interakcję międzyludzką i nie utrudniają nawiązywania relacji.

Wnioski wyciągnięte z przeprowadzonej analizy wskazują na bardzo ważną rolę osób projektujących przestrzeń, czyli architektów, urbanistów, planistów, którzy posiadają wiedzę na temat wpływu przestrzeni na relacje międzyludzkie. To oni poprzez plany, projekty czy regulacje prawne mogą przyczyniać się do rozwoju tzw. przestrzeni przyjaznych, z których ludzie będą korzystali chętnie i bez ograniczeń, budując relacje, oddziałując na siebie wzajemnie i tworząc więzy oraz wspólnoty.

O bezpieczeństwo, które jest ważnym czynnikiem wpływającym na chęć zamieszkiwania osiedli zamkniętych, powinni dbać architekci i sami mieszkańcy. Powstają koncepcje alternatywne, mające sprawić, że ogrodzenie nie będzie potrzebne do zapewnienia bezpieczeństwa mieszkańcom. CPTED (crime prevention through environmental design) to jedna z koncepcji, która powstała w USA i Kanadzie, mająca na celu tworzenie takich przestrzeni, które poprzez swój projekt będą zwiększały stopień bezpieczeństwa [Ray Jeffery 1972, s. 191]. Autorem tej koncepcji jest C. Ray Jeffery, który dążył do tego, aby wyeliminować z przestrzeni wszystkie elementy zachęcające do dokonania przestępstwa. 
Ponadto, w tego typu projektach istotną rolę odgrywają mieszkańcy, którzy dzięki umożliwionej obserwacji mogą stać się „strażnikami swojego podwórka”. Tym samym to właśnie sami mieszkańcy zapewniają sobie bezpieczeństwo. Ważne są ich sąsiedzkie relacje, wzajemne zaufanie i znajomość. J. Jacobs w swojej pracy, mówiąc o miastach amerykańskich wskazywała, że współpraca sąsiedzka odgrywa kluczową rolę przy tworzeniu przestrzeni publicznych i w późniejszym ich bezpieczeństwie [Jacobs 2014]. Autorka wspomina o tzw. oczach na ulicy, czyli ludziach obserwujących, którzy stanowią najlepszą ochronę dla mieszkańców. Teorie te zostały rozwinięte przez O. Newmana, który nakreślił koncepcję defensive space [Crowe i Zahm 1994, s. 22-27]. Uważał on, że poprzez tworzenie małych, spójnych jednostek sąsiedzkich można uczynić ludzi odpowiedzialnymi za swoją przestrzeń. Mieszkańcy czuliby, że powinni dbać o swoje otoczenie i je ochraniać.

Amerykańskie idee i koncepcje zostały rozwinięte w niektórych częściach Europy. Jednym z ciekawych przykładów wprowadzania takich rozwiązań jest koncepcja „bezpieczeństwo poprzez projekt” (secure by design), realizowana w Wielkiej Brytanii i w Holandii. Realizacje takie pojawiły się także w Polsce ${ }^{3}$. Design, czyli projekt ma zapewnić powstanie przestrzeni bezpiecznej. Zgodnie z tą koncepcją to architekci są odpowiedzialni za bezpieczeństwo na osiedlach, a nie firmy ochroniarskie czy monitoring. Priorytetem jest, aby przestrzenie na takich osiedlach były dobrze oświetlone i przejrzyste, i nie występowały wnęki czy zakamarki.

Na bezpieczeństwo osiedla duży wpływ ma utworzona na terenie osiedla wspólnota lokalna. Nieformalne przestrzenie, w których sąsiedzi mogą spotykać się ze sobą, dają poczucie wspólnoty utworzonej na terenie miejsca zamieszkania i umożliwiają zaistnienie więzi lokalnych. Te elementy wystarczają, aby znacznie spadły wskaźniki przestępczości na danym obszarze. Bezpieczeństwo jest też warunkowane przez wzajemne zaufanie i współdziałanie mieszkańców. Zaangażowanie i współpracowanie sąsiadów jest kluczowe. Utworzenie się wspólnoty zmniejsza wskaźniki przestępczości, ale również przyczynia się do powstawania innych pozytywnych skutków. Zastosowanie rozwiązań, które będą podnosić bezpieczeństwo osiedli, a nie będą wpływać na ich izolację od otoczenia, jest możliwe i powinny być one wprowadzane w fazie projektu, co dodatkowo podkreśla istotną rolę projektanta, architekta i planisty w procesie kreowania relacji międzyludzkich.

\footnotetext{
${ }^{3}$ Przykłady osiedli, które są budowane zgodnie z zasadami secure by design w Polsce, to m.in. osiedle Novalia w Siedlcach pod Wrocławiem, osiedle Panorama przy ul. Widokowej 4 w Rzeszowie i osiedle Wisłok przy ul. L. Siemieńskiego w Rzeszowie.
} 


\section{Literatura}

Crowe T.D., Zahm D.L. [1994], Crime Prevention through Environmental Design, „Land Development", Fall.

Dymnicka M. [2007], Osiedla za bramq a ciqgłość kulturowa i społeczna w kształtowaniu przestrzeni miejskiej [w:] Gettoizacja polskiej przestrzeni miejskiej, red. B. Jałowiecki, W. Łukowski, Wydawnictwo Naukowe Scholar, Warszawa.

Gądecki J. [2007], „Za murami” - krytyczna analiza dyskursu na temat osiedli typu gated communities w Polsce [w:] Gettoizacja polskiej przestrzeni miejskiej, red. B. Jałowiecki, W. Łukowski, Wydawnictwo Naukowe Scholar, Warszawa.

Grant J., Mittelsteadt L. [2004], Types of Gated Communities, „Environment and Planning B: Planning and Design", vol. 31, https://doi.org/10.1068/b3165.

Jacobs J. [2014], Śmierć i życie wielkich miast Ameryki, Centrum Architektury, Warszawa. Jałowiecki B. [2007], Fragmentacja i prywatyzacja przestrzeni [w:] Gettoizacja polskiej przestrzeni miejskiej, red. B. Jałowiecki, W. Łukowski, Wydawnictwo Naukowe Scholar, Warszawa.

Jałowiecki B. [2010], Społeczne wytwarzanie przestrzeni, Wydawnictwo Naukowe Scholar, Warszawa.

Karwińska A. [2008], Gospodarka przestrzenna. Uwarunkowania społeczno-kulturowe, Wydawnictwo Naukowe PWN, Warszawa.

Le Goix R., Webster Ch. [2006], Gated Communities, Sustainable Cities and a Tragedy of the Urban Commons, „Critical Planning”, nr 13.

Ray Jeffery C. [1972], Crime Prevention Through Environmental Design, „Criminology”, vol. 10, nr 2, https://doi.org/10.1111/j.1745-9125.1972.tb00553.x

Szczepańska M. [2012], Osiedla grodzone: Świadomościowe aspekty podziałów społeczno-przestrzennych i więź sq̨siedzka, „Przestrzeń Społeczna”, nr 1/2012 (3).

Szczepański M., Ślęzak-Tazbir W. [2007], Między lękiem a podziwem: getta społeczne w starym regionie przemysłowym [w:] Gettoizacja polskiej przestrzeni miejskiej, red. B. Jałowiecki, W. Łukowski, Wydawnictwo Naukowe Scholar, Warszawa.

Tobiasz-Lis P. [2011], Osiedla grodzone w Łodzi. Przyczyny i konsekwencje zjawiska, „Space - Society - Economy”, nr 10, Łódź.

Węcławowicz G. [2007], Geografia społeczna miast, Wydawnictwo Naukowe PWN, Warszawa.

\section{Gated Estates and an Evaluation of Gating Forms in Krakow's Podgórze District}

(Abstract)

The rising number of gated estates, usually created as autonomic units and which stand out from their surroundings, contributes to the fragmentation of the urban environment and has been roundly criticised. The article identifies the causes and effects of creating gated estates in Polish cities, as well as the forms of their gating and opinions about them. The analysis was conducted in the Podgórze district, which has a significant number of such estates. The study confirms the critical views that have been expressed elsewhere in the subject literature about gated estates. However, it is the form of gating, 
or fencing, that plays an important role in the arrangement of space, which in fact creates public opinion. The form of gating can influence not only the relationships inside gated areas, but also the relationship inhabitants have with the external environment. This leads to the conclusion that each of them should be analyzed separately.

Keywords: fenced estates, ghettoization, Podgórze district, Cracow, cities. 